Crop Breeding and Applied Biotechnology 13: 59-66, 2013

Brazilian Society of Plant Breeding. Printed in Brazil

\title{
ARTICLE
}

\section{Application of LW7 marker for identification of progenies with male sterility gene in sweet sorghum population}

\author{
Darika Bunphan $^{1}$, Prasit Jaisil ${ }^{1 *}$ and Jirawat Sanitchon ${ }^{1}$
}

Received 13 July 2012

Accepted 08 October 2012

\begin{abstract}
The objectives of this study were to verify the use of $L W 7$ marker in identifying maintainer lines (B-lines) and restorer lines (R-lines) in grain sorghum and sweet sorghum, and to identify $B$-lines in the $F_{2}, B C_{1} F_{2}$ and $B C_{2} F_{2}$ generations. Twenty five accessions of sorghum were evaluated, and LW7 marker correctly identified accessions which presented male sterility gene (rf4) in Suphan Buri1 and 03B cultivars; moreover, these genotypes did not show $779 \mathrm{bp}$ band. The cross between Suphan Buril and a male-sterile line (A-line) $03 A$ resulted in a sterilized male, confirming the usefulness of the marker in breeding programs. $B$-lines in the $F_{2}, B C_{1} F_{2}$ and $\mathrm{BC}_{2} \mathrm{~F}_{2}$ generations were identified by $L W 7$ marker. The segregation ratio of 3:1 for male fertility and male sterility in the progenies of the three generations supported the one-gene model of Mendelian segregation. The use of marker assisted selection was successful for line development of sweet sorghum with male sterility.
\end{abstract}

Key words: Cytoplasmic genetic male sterile, restorer gene, energy crop, marker assisted selection.

\section{INTRODUCTION}

Agriculture provides fiber, food and fuel to human being, and energy from renewable sources is very important due to the depletion of non-renewable crude oil (Ratnavathi et al. 2011). Bio-ethanol production, for example, is an effective way to convert excessive supply of agricultural products (sugarcane and cassava) into value-added of transportation fuel. However, bio-ethanol industry competes for raw material with other industries such as sugar, animal feed and cassava starch, leading to unstable supply chain of raw material and fluctuation of its price. Sweet sorghum can fill the gap of raw material shortage and extend the operation season of bio-ethanol factories for few months.

Extensive research on sweet sorghum has been carried out in many countries such as in China (Gnansounou et al. 2005), India (Reddy et al. 2005), the Philippines (Reddy et al. 2011), the United States, Australia (Reddy et al. 2010a) and Europe countries (Berenji and Dahlberg 2004). Development of hybrid varieties is an approach to improve yield potential of sweet sorghum (Yu and Cuizhen 1998, Reddy et al. 2010a). Since the discovery of male sterility in sorghum (Stephens and Holland 1954), hybrid varieties have been used extensively for grain sorghum. An attempt to converse male sterility into sweet sorghum has been made (Reddy et al. 2010b); moreover, the research on heterosis among germplasm accessions (Pfeiffer et al. 2010) and related species has also been carried out (Murray et al. 2009, Wang et al. 2009). Some experimental hybrids of $A_{3}$ male sterility showed better performance for brix and stalk yield than their parents (Pfeiffer et al. 2010); additionally, Makanda et al. (2009) reported that the hybrids had performance for brix higher than parents and exhibited heterosis of up to $112 \%$.

Marker assisted selection can accelerate breeding program. DNA-based molecular markers tightly linked to fertility restorer genes have also been identified in several other species such as rice (Akagi et al. 1996, Ichikawa et al. 1997, Zhang et al. 1997), petunia (Bentolila et al. 1998, Bentolila and Hanson 2001), barley (Matsu et al. 2001), sunflower (Horn et al. 2003), cotton (Gossypium hirsutum; Liu et al. 2003), wheat (Zhou et al. 2005), chili pepper (Kim et al. 2006) and sorghum (Klein et al. 2001, Jordan et al. 2010, Jordan et al. 2011). In sweet sorghum, DNA markers associated with several morphological traits (Shehzad et al. 2009), agronomic traits (Yun-long et al. 2006, Ritter et al. 2008, Murray et al. 2009) and stem sugar-related traits (Ritter et al. 2008, Shiringani et al. 2010) have been identified and mapped into sorghum genetic linkage map (Ritter et al. 2007, Srinivas et al. 2009). Several DNA markers are associated

\footnotetext{
${ }^{1}$ Khon Kaen University, Faculty of Agriculture, Department of Plant Science and Agricultural Resources, 40002, Khon Kaen, Thailand. * E-mail: pjaisil@gmail.com
} 
with male fertility in sorghum, including AFLP Xtxa2582; two SSRs, Xtxp18 and Xtxp250 (Klein et al. 2001); SSR Xtxp304 (Jordan et al. 2010); LW7; LW8; and LW9 marker (Wen et al. 2002). These markers provide a powerful tool for practical breeding of sweet sorghum hybrids.

Markers associated with male fertility such as LW7, LW8 and LW9 were screened for their efficacy in identifying restorer genes in grain sorghum and sweet sorghum populations in breeding program at Khon Kaen University. LW8 and LW9 were discarded from the project since these markers were not effective in identifying the correct genotypes. Nevertheless, LW7 was polymorphic and was selected for use in marker assisted selection program (Lunmat et al. 2008). LW7 was extensively used in grain sorghum (Wen et al. 2002). However, the application in sweet sorghum to develop B-lines has not been reported. The objectives of this study were to verify the use of LW7 marker in identifying maintainer lines (B-lines) and restorer lines (R-lines) in grain sorghum and sweet sorghum and to select $\mathrm{B}$-lines in the $\mathrm{F}_{2}, \mathrm{BC}_{1} \mathrm{~F}_{2}$ and $\mathrm{BC}_{2} \mathrm{~F}_{2}$ segregating populations.

\section{METERIALS AND METHODS}

\section{Plant materials}

Twenty six cultivars and lines of sweet sorghum, grain sorghum and forage sorghum were used in this study. Eighteen cultivars were sweet sorghum from different sources. The cultivars Keller, Theis, Wray, Cowley and Bailey were introduced from the United States (Murray et al. 2009). Urja was introduced from Praj Co.Ltd., India. SSV84 and SV74 were introduced from the International Crops Research Institute for the Semi-Arid Tropics (ICRISAT), India. BJ248 and BJ281 were from China (Audilakshmi et al. 2010). Suwan Sweet1, Suwan Sweet2, Suwan Sweet3, Suwan Sweet4, Suwan Sweet5, DA5 and KD1 were developed by Kasetsart University, Thailand; and KKU40 was developed by the Department of Plant Science and Agricultural Resources, Faculty of Agriculture, Khon Kaen University, Thailand (Ariyajaroenwong et al. 2012).

Five cultivars of grain sorghum (KU439, KU630, KU804, KU901 and KU905) were kindly donated by Kasetsart University, Thailand. A forage sorghum cultivar (Suphan Buri1), which had been previously identified with the male sterility gene, was kindly donated by Suphan Buri Agricultural Research and Development Center, Thailand; and a B line (03B) of grain sorghum was kindly donated by Kasetsart University, Thailand. These B lines were used as checks for male sterility and were also used as parent to transfer male sterility to sweet sorghum. A male-sterile line (A-line) (A1 cytoplasm) of grain sorghum was kindly donated by Kasetsart University, Thailand, which was also used as female parent. The genetics for male sterility in other genotypes were not previously known, and they were selected for the experiment due to its good yield and agronomic traits.

Twenty-five genotypes (except for A-line) were planted in single row plots of $5 \mathrm{~m}$ long, spaced $50 \mathrm{~cm}$ between rows and $10 \mathrm{~cm}$ between plants, in late February 2010. The line 03B (B-line) was also planted and used as check. Twentyfive sorghum cultivars were crossed with A-line sorghum and the $\mathrm{F}_{1}$ crosses were planted in the next season.

Three hundred and fifteen plants in the $\mathrm{F}_{2}$ generation, derived from the cross between a B-line of grain sorghum (03B), and a high yielding sweet sorghum (SSV84) were used as initial population in this study. The hybridization of this $F_{2}$ population was carried out in the earlier work. The $\mathrm{F}_{2}$ plants were planted in rows, spaced $50 \mathrm{~cm}$ between rows and $30 \mathrm{~cm}$ between plants. B-lines in $\mathrm{F}_{2}$ population were identified by LW7 marker, then backcrossed were done with SSV84 for three times, in order to transfer male sterility to sweet sorghum background. The backcross was accomplished by marker assisted selection. Six hundred and twenty two plants of $\mathrm{BC}_{1} \mathrm{~F}_{2}$ population and five hundred and thirty seven plants of $\mathrm{BC}_{2} \mathrm{~F}_{2}$ population derived from the progenies with genes conferring male sterility in the $\mathrm{F}_{2}$ populations were screened for gene conferring male sterility, the selected genotypes were crossed with SSV84 and the $\mathrm{F}_{1}$ generations were allowed to self-pollinate.

\section{DNA extraction}

One-month old plants were used for DNA extraction. The entries consisted of 25 lines/cultivars, and the single plants in the $\mathrm{F}_{2}$ population derived from the cross between 03B and SSV84. The 25 lines/cultivars were used for screening for male sterile genes (rf4rf4), whereas the $\mathrm{F}_{2}, \mathrm{BC}_{1} \mathrm{~F}_{2}$ and $\mathrm{BC}_{2} \mathrm{~F}_{2}$ populations were used for screening of progenies that carry male sterile genes (rf4rf4).

A newly fully-expanded leaf of each plant was used for DNA extraction. Two plants were sampled individually for 25 lines/cultivars, and single plants were used for the $\mathrm{F}_{2}, \mathrm{BC}_{1} \mathrm{~F}_{2}$ and $\mathrm{BC}_{2} \mathrm{~F}_{2}$ segregating populations. Leaf samples of $3 \mathrm{~g}$ were collected from 4-week-old field-grown plants and snap frozen in liquid nitrogen. DNA extraction was done according to the method described by Dellaporta et al. (1983), with minor alteration. One percent agarose gel electrophoresis was used to cross checked quantity and quality of DNA and compared to $\lambda$-DNA, which is a standard check.

\section{PCR conditions and gel electrophoresis}

PCR was carried out in $20 \mu \mathrm{l}$ reaction mixture containing $50 \mathrm{ng}$ of DNA template, $1 \mathrm{X}$ PCR buffer, $0.2 \mathrm{mM}$ dNTPs, $1.8 \mathrm{mM} \mathrm{MgCl}_{2}, 1$ Unit Taq polymerase, $0.25 \mu \mathrm{l} \mathrm{E-CTA} / 5$ '- 
GATCTACATATGTGGAGCTC-3' and M-CAC/5'AGAT CTCGGCGCTGCGGAGCAGAA-3' of LW7 marker (Wen et al. 2002), and $6.96 \mu \mathrm{l}$ of $\mathrm{dH}_{2} \mathrm{O}$.

The standardized amplification/PCR condition was set with minor modification at pre-denaturation at $95^{\circ} \mathrm{C}$ for 3 minutes, 35 cycles of denaturation at $94^{\circ} \mathrm{C}$ for 30 seconds, annealing at $58^{\circ} \mathrm{C}$ for 60 seconds (changed to $60^{\circ} \mathrm{C}$ for 90 seconds), extension at $72^{\circ} \mathrm{C}$ for 60 seconds (changed to 120 seconds) followed by final extension at $72{ }^{\circ} \mathrm{C}$ for 5 minutes. The amplified PCR products were then separated on $2 \%$ agarose gel electrophoresis. Bands were then scored (1) for presence or $(0)$ for absence of banding at $779 \mathrm{bp}$ (Wen et al. 2002). The data of PCR reactions were recorded as 1 or 0 for the presence of $779 \mathrm{bp}$ or absence of the bands, respectively.

\section{Data analysis}

The data of 25 sorghum genotypes were used merely for screening of these genotypes for the lines, which possess male sterility gene (rf4). The binary data of PCR reactions for 315 plants in the $\mathrm{F}_{2}$ generation, 622 plants of $\mathrm{BC}_{1} \mathrm{~F}_{2}$ population and 537 plants of $\mathrm{BC}_{2} \mathrm{~F}_{2}$ generation were analyzed by Chi-square $\left(\chi^{2}\right)$ test (Gomez and Gomez 1984) as follows: $\chi^{2}=\sum_{i=1}^{k} \frac{(O i-E i)^{2}}{E i}$, where $\chi^{2}=$ Chi-square, $\mathrm{O}_{\mathrm{i}}=$ frequencies of observed value, $\mathrm{E}_{\mathrm{i}}=$ frequencies of expected value. The Chi-square test would verify the segregating models of the progenies.

\section{RESULTS AND DISCUSSION}

In this study, 25 genotypes of sorghum were used for screening of genotypes containing male sterile genes $(r f 4)$ by using a molecular marker. Once the lines were identified, they were used in the crossing program to transfer male sterility genes into sweet sorghum background and backcross was carried out three times. Marker assisted selection was used for screening progenies with male sterility genes.

\section{Banding in lines and cultivars}

Twenty three of 25 cultivars/lines produced a band of 779 bp of LW7 marker flanking the male fertile restorer genes (Rf4) (Figure 1). Suphan Buri1 (SP1) and the line 03B did not show this specific band (Figure 1), and they were previ- ously known as the genotypes with gene conferring male sterility (rf4). The results indicated that the marker could identify correctly the sorghum genotypes which present male restorer gene.

The test crosses of 25 sorghum genotypes with the line $03 \mathrm{~A}$ (an A line) was also carried out to confirm the results. As expected, the 23 sorghum genotypes with $R f 4$ gene did not show male sterility, whereas the pure lines Suphan Buril and $03 \mathrm{~B}$ that had $r f 4$ gene produced $\mathrm{F}_{1}$ plants showing male sterility (Data not reported). The results were very convincing to apply molecular assisted selection in this sweet sorghum breeding program.

LW7 was identified and subsequently converted to STS/ CAPS marker. This marker is small (214 bp) and AT-rich, which generated a $779 \mathrm{bp}$ at fertility restorer gene, and the LW7 marker is closely linked with Rf4 gene (5.13 bp) (Wen et al. 2002). Therefore, identification of B-line in grain, sweet and forage sorghum and B-lines in three segregating populations of sorghum is very effective.

\section{Marker assisted selection in segregating populations}

Molecular assisted selection using LW7 marker was employed in three consecutive populations $\left(\mathrm{F}_{2}, \mathrm{BC}_{1} \mathrm{~F}_{2}\right.$ and $\mathrm{BC}_{2} \mathrm{~F}_{2}$ ) from the cross of a $\mathrm{B}$-line (03B) of grain sorghum and a high yielding sweet sorghum (SSV84). In the $\mathrm{F}_{2}$ generation, a total number of 315 plants were screened for a band of $779 \mathrm{bp}$ using LW7 molecular marker (Figure 2A). Two hundred and forty three plants showed the band of $779 \mathrm{bp}$, and 72 plants did not (Table 1). The segregation ratio of 3:1 conformed to one-gene model of Mendelian segregation ratio (1RfRf:2Rfrf: $1 r f r f)$.

In the $\mathrm{BC}_{1} \mathrm{~F}_{2}$ generation, 622 plants were screened using LW7 marker. Four-hundred and sixty nine plants showed the band of $779 \mathrm{bp}$, and 153 plants did not (Figure 2b). The segregation ratio of 3:1 was in good agreement with onegene model of Mendelian segregation ratio. In the $\mathrm{BC}_{2} \mathrm{~F}_{2}$ generation, 537 plants were screened. Four hundred and eight plants showed the band of $779 \mathrm{bp}$, and 129 did not. Again, the segregation ratio of $3: 1$ also conformed to Mendelian segregation for one-gene model (Table 1).

Table 1. Segregation ratio of fertile to sterile plants of sweet sorghum in the $\mathrm{F}_{2}, \mathrm{BC}_{1} \mathrm{~F}_{2}$ and $\mathrm{BC}_{2} \mathrm{~F}_{2}$ populations

\begin{tabular}{lllllll}
\hline Generation & Total & Expected ratio & Observed ratio & Test ratio & $\chi^{2}$ & Probability $(0.01)$ \\
\hline $\mathrm{F}_{2}$ & 315 & $236: 79$ & $243: 72$ & $3: 1$ & $0.62^{n s}$ & $0.50-0.25$ \\
$\mathrm{BC}_{1} \mathrm{~F}_{2}$ & 622 & $466: 156$ & $469: 153$ & $3: 1$ & $0.06^{n s}$ & $0.90-0.75$ \\
$\mathrm{BC}_{2} \mathrm{~F}_{2}$ & 537 & $403: 134$ & $408: 129$ & $3: 1$ & $0.19^{n s}$ & $0.75-0.50$ \\
\hline$n s:$ non-significant & & & &
\end{tabular}


Darika Bunphan et al.
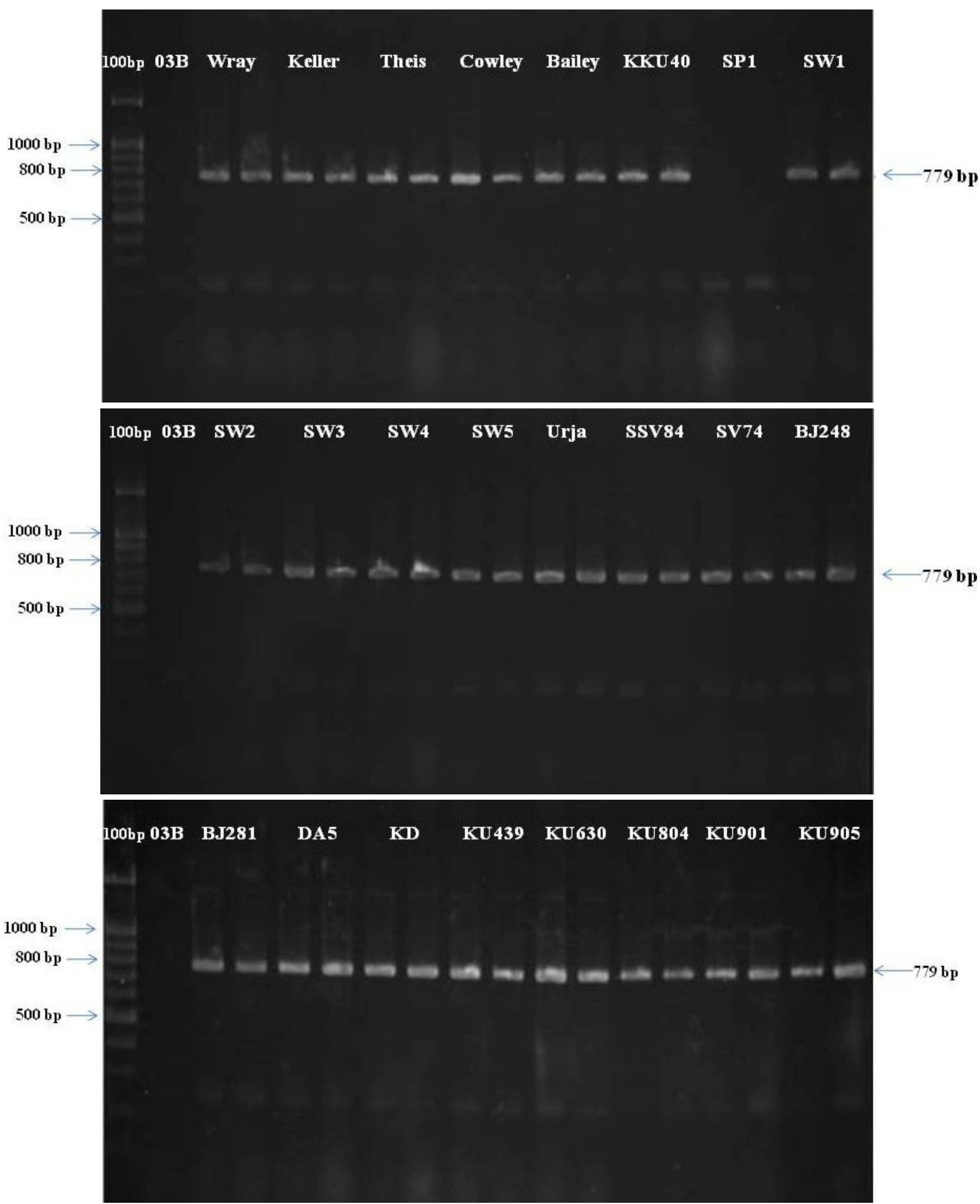

Figure 1. Agarose gel electrophoresis of DNA fragments of 25 sorghum genotypes obtained from PCR reaction of LW7 marker. Note: $03 \mathrm{~B}-$ a B line sorghum, SP1- a cultivar with known genetic background for male sterility. One lane is used for 03B and two lanes were used for other. 

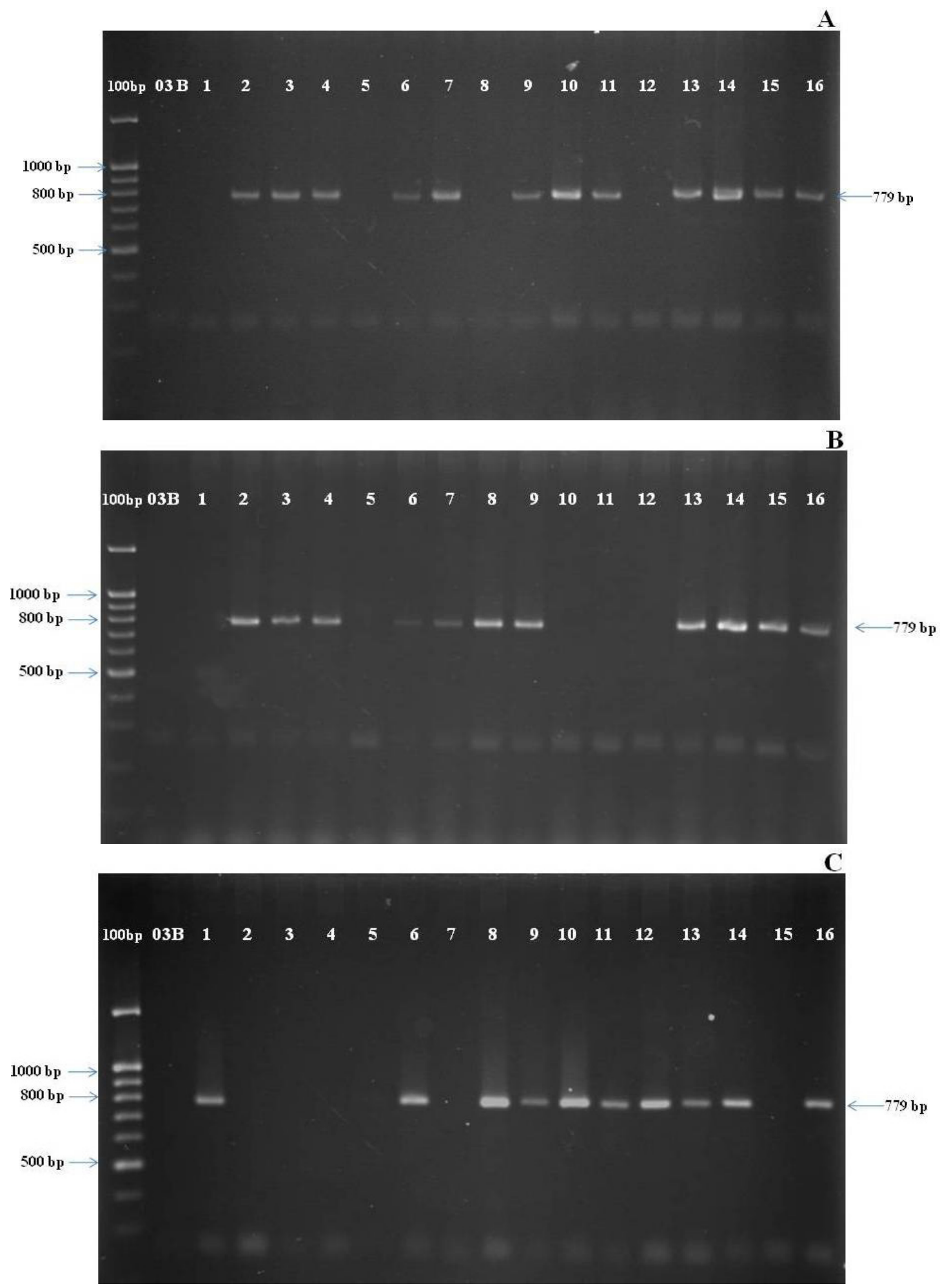

Figure 2. Agarose gel electrophoresis of DNA fragments of individual plants in the $\mathrm{F}_{2}$ generation $(\mathrm{A}), \mathrm{BC}_{1} \mathrm{~F}_{2}$ generation $(\mathrm{B})$ and $\mathrm{BC}_{2} \mathrm{~F}_{2}(\mathrm{C})$ obtained from PCR reactions of LW7 marker. Note: 03B- a B line sorghum used as check. 
LW7, LW8 and LW9 are STS or CAPS markers, two of which are co-dominant (Wen et al. 2002). LW7 is a dominance marker and, therefore, it cannot identify homozygous and heterozygous genotypes. However, this marker can identify rf4rf4 genotypes correctly. Although LW8 and LW9 are co-dominance markers, they are not applicable to this population, and they were discarded from the experiment (Lunmat et al. 2008). However, in

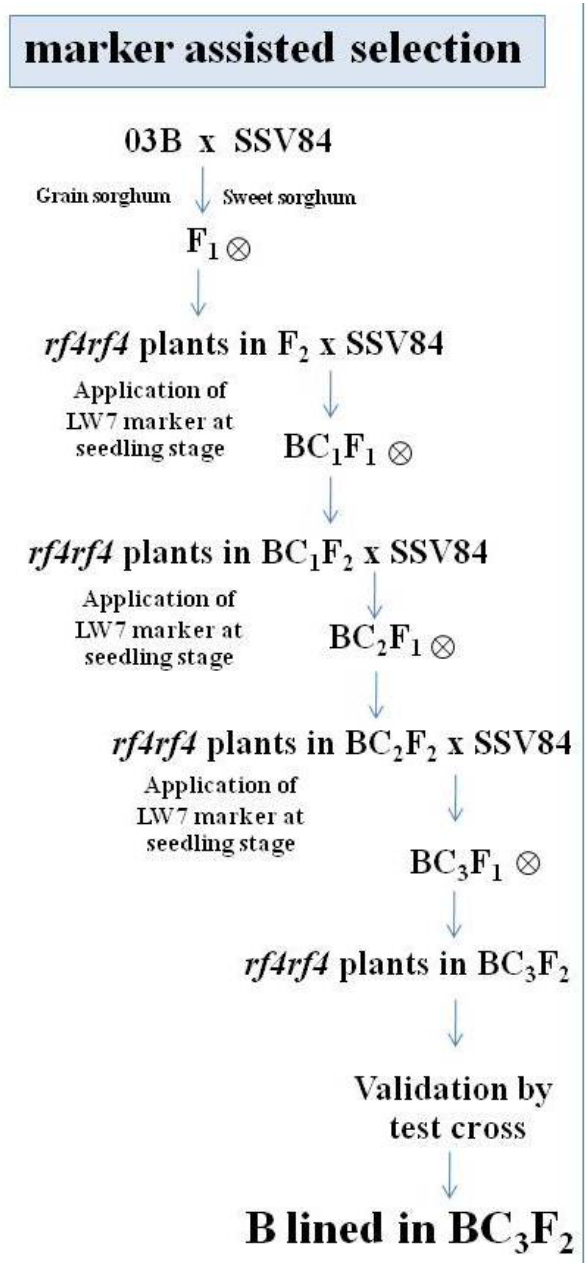

Figure 3. The diagram shows comparison of marker assisted selection and conventional method. this study, the interest is stalk yield rather than grain yield, since new B-line and A-line sweet sorghum are being developed. Wen et al. (2002) successfully used LW7, LW8 and LW9 markers for identifying R-line sorghum due to of its close links with restorer gene (Rf4) 5.133 .18 and $0.79 \mathrm{cM}$, respectively. However, LW8 and LW9 markers could not identify R-line and B-line in $\mathrm{F}_{2}$ population (Lunmat et al. 2008).

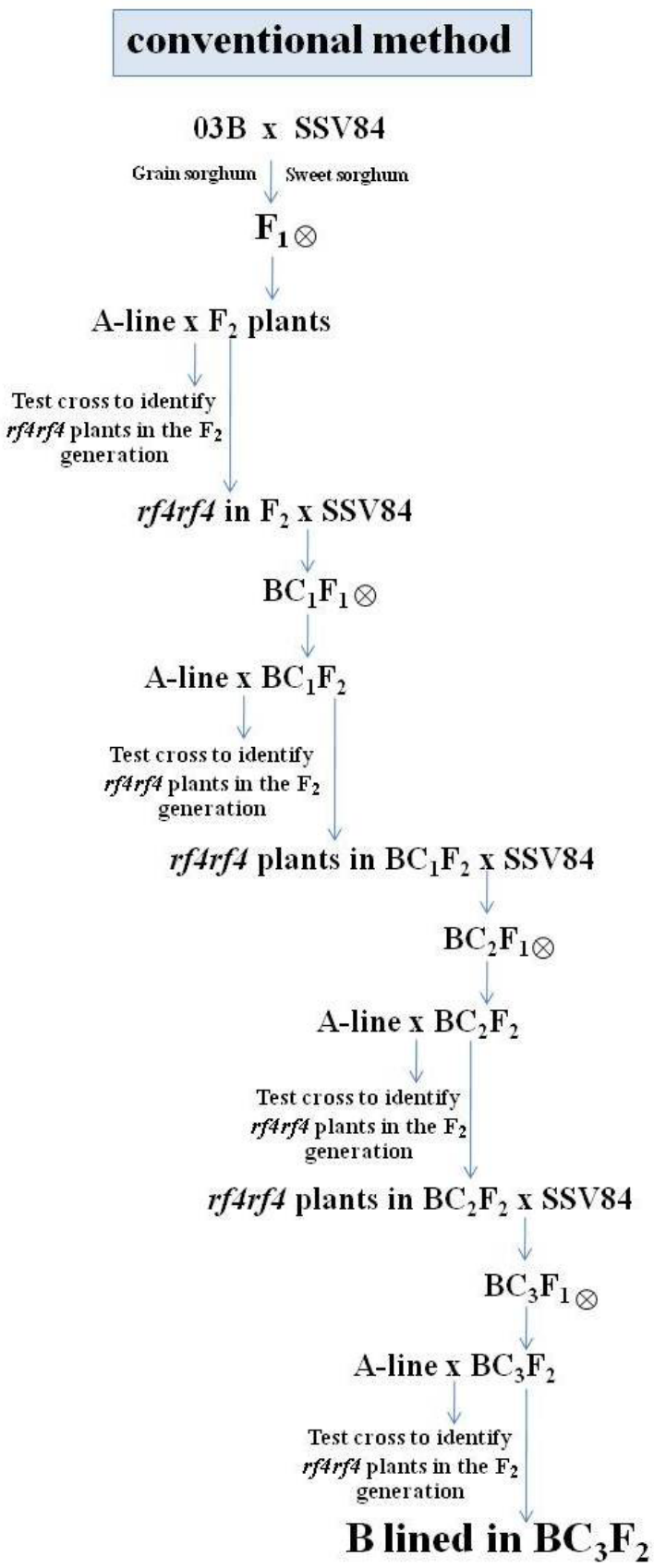




\section{Comparison of marker assisted selection and conventional method}

Schematic diagrams of marker assisted selection and conventional selections are presented in Figure 2. It is clear that marker assisted selection can reduce the time required for line development. This is due to the fact that this method does not require progeny test for each cycle of backcrossing. Moreover, this method also reduces costs for labor and progeny trials, and it may also reduce population size for line selection.

Marker assisted selection requires well-equipped laboratory and the cost for line development may be higher than conventional method. However, the method is faster, leading to the rapid release of new cultivars. This seems to be advantageous under high competition of seed industry. Under situation where labor cost is not expensive and time for line development is not demanding, conventional method may be more suitable than marker assisted selection.

Marker assisted selection for male sterility in sweet sorghum was completed in nine seasons. The marker LW7 was successfully used for line development. Due to time limit, gene validation was not performed. The efficiency of the method compared to the conventional one was not determined, and further investigations are required. This study proved that marker assisted selection for male sterility using LW7 marker was effective.

\section{ACKNOWLEDGEMENTS}

This research was funded by the Royal Golden Jubilee Ph.D. Program (RGJ) under the Thailand Research Fund, Plant Breeding Research Center for Sustainable Agriculture, Department of Plant Science and Agricultural Resources, Faculty of Agriculture and Khon Kaen University Research Fund.

\section{Aplicação do indicador LW7 para a identificação de progênies com gene de esterilidade masculina na população de sorgo sacarino}

Resumo - Verificou-se o uso do marcador LW7 para identificação de linhas mantenedoras $B$ e restauradoras $R$ em sorgo granífero e doce e para identificação de linhas mantenedoras $B$ nas gerações $F_{2}, R C_{1} F_{2}$ e $R C_{2} F_{2}$. Vinte e cinco acessos de sorgo foram avaliados e o marcador LW7 identificou corretamente aqueles que possuem o gene de macho-esterilidade (rf4) como Suphan Buril e 03B, os quais não mostraram a banda de 779 pb. O cruzamento entre Suphan Buril e uma linha macho-estéril (A) 03A resultou macho-estéril, confirmando a utilidade do marcador em programas de melhoramento. Linhas $B$ em gerações $F_{2}, R C_{1} F_{2}$ e $R C_{2} F_{2}$ foram identificadas pelo marcador LW7 e a taxa de segregação de 3:1 para fertilidade e macho-esterilidade nas progênies das três gerações apoiaram o modelo de segregação Mendeliana de um gene. O uso da seleção assistida por marcador foi bem sucedido para o desenvolvimento de linhas de sorgo sacarino com macho-estéreis.

Palavras-chave: Genética citoplasmática de macho-estéril, gene restaurador, culturas energéticas, seleção assistida por marcadores.

\section{REFERENCES}

Akagi H, Yokozeki Y, Inagaki A, Nakamura A and Fujimura T (1996) A co-dominant DNA marker closely linked to the rice nuclear gene, $R f 1$, identified with inter-SSR fingerprinting. Genome 39: 205-1209.

Ariyajaroenwong P, Laopaiboon P, Jaisil P and Laopaiboon L (2012) Repeated-Batch ethanol production from sweet sorghum juice by Saccharomyces cerevisiae immobilized on sweet sorghum stalks. Energies 5: 1215-1228.

Audilakshmi S, Mall AK, Swarnalatha M and Seetharama N (2010) Inheritance of sugar concentration in stalk (brix), sucrose content, stalk and juice yield in sorghum. Biomass and Bioenergy 34: 813-820.

Bentolila S and Hanson MR (2001) Identification of a BIBAC clone that co-segregates with the petunia restorer of fertility $(R f)$ gene. Molecular Genetics and Genomics 266: 223-230.

Bentolila S, Zethof J, Gerats T and Hanson MR (1998) Locating the petunia $R f$ gene on a $650 \mathrm{~kb}$ DNA fragment. Theoretical and Applied Genetics 96: 980-988.
Berenji J and Dahlberg J (2004) Perspective of sorghum in Europe. Journal of Agronomy and Crop Science 190: 332-338.

Dellaporta SL, Wood J and Hicks JB (1983) A plant DNA mini-preparation: version II. Plant molecular biology reporter 1: 19-21.

Gnansounou E, Dauriat A and Wyman CE (2005) Refining sweet sorghum to ethanol and sugar: economic trade-offs in the context of North China. Bioresource Technology 96: 985-1002.

Gomez KA and Gomez AA (1984) Statistical procedures for agricultural research. John Wiley and Sons, New York, 680p.

Horn R, Kusterer B, Lazarescu E, Prufe M and Friedt W (2003) Molecular mapping of the $R f 1$ gene restoring pollen fertility in PET1-based $\mathrm{F}_{1}$ hybrids in sunflower (Helianthus annuus L.). Theoretical and Applied Genetics 106: 599-606.

Ichikawa N, Kishimoto N, Inagaki A, Nakamura A, Koshino Y, Yokozeki Y, Oka M, Samoto S, Akagi H, Higo K, Shinjyo C, Fujimura T and Shimada H (1997) A rapid PCR-aided selection of a rice line containing the $R f 1$ gene which is involved in restoration of the cytoplasmic male sterility. Molecular Breeding 3: 195-202. 
Jordan DR, Mace ES, Henzell RG, Klein PE and Klein RR (2010) Molecular mapping and candidate gene identification of the Rf2 gene for pollen fertility restorer in sorghum (Sorghum bicolor (L.) Moench). Theoretical and Applied Genetics 120: $1279-1287$.

Jordan DR, Klein RR, Sakrewski KG, Henzell RG, Klein PE and Mace ES (2011) Mapping and characterization of Rf5: a new gene conditioning pollen fertility restoration in A1 and A2 cytoplasm in sorghum (Sorghum bicolor (L.) Moench). Theoretical and Applied Genetics 123: 383-396.

Kim DS, Kim DH, Yoo JH and Kim BD (2006) Cleaved amplified polymorphic sequence and chilli pepper (Capsicum annuиm L.). Molecules and Cells 21: 135-140.

Klein RR, Klein PE, Chhabra AK, Dong J, Pammi S, Childs KL, Mullet JE, Rooney WL and Schertz KF (2001) Molecular mapping of the rf1 gene for pollen fertility restoration in sorghum (Sorghum bicolor L.). Theoretical and Applied Genetics 102: 1206-1212.

Liu L, Guo W, Zhu X and Zhang T (2003) Inheritance and fine mapping of fertility restoration for cytoplasmic male sterility in Gossypium hirsutum L. Theoretical and Applied Genetics 106: 461-469.

Lunmat N, Jaisil P, Sanitchon J and Puangsomlee Wangsomnuk P (2008) Development of B-lines for using to develop A-lines of sweet sorghum (Sorghum bicolor (L.) Moench). Khon Kaen Agriculture Journal (inThai with English abstract) 36: 19-25.

Makanda I, Pangirayi T and John D (2009) Combining ability and heterosis of sorghum germplasm for stem sugar traits under off-season conditions in tropical lowland environments. Field Crops Research 114: $272-279$.

Matsu K, Mano Y, Taketa S, Kawada N and Komatsuda T (2001) Molecular mapping of a fertility restoration locus $(R f m l)$ for cytoplasmic male sterility in barley (Hordeum vulgare L.). Theoretical and Applied Genetics 102: 477-282.

Murray SC, William LR, Martha TH, Sharon EM and Stephen K (2009) Sweet sorghum genetic diversity and association mapping for brix and height. The Plant Genome 2: 48-62.

Pfeiffer TW, Bitzer MJ, Toy JJ and Petersen JF (2010) Heterosis in sweet sorghum and selection of a new sweet sorghum hybrid for use in syrup production in Appalachia. Crop Science 50: 1788-1794.

Ratnavathi CV, Chakravarthy SK, Komala VV, Chavan UD and Patil JV (2011) Sweet sorghum as feedstock for bio-fuel production: a review. Sugar Tech 13: 399-407.

Reddy BVS, Kumar AA and Reddy PS (2010a) Recent advances in sorghum improvement research at ICRISAT. Kasetsart Journal (Nat. Sci.) 44: 499-506.

Reddy BVS, Layaoen H, Dar WD, Srinivasa RP and Eusebio JE (eds.) (2011) Sweet sorghum in the Philippines: status and future. International Crops Research Institute for the Semi-Arid Tropics, Patancheru, 116p.
Reddy BVS, Ramesh S, Reddy PS, Ramaiah B, Salimath M and Kachapur R (2005) Sweet sorghum a potential alternate raw material for bio-ethanol and bio-energy. International Sorghum and Millets Newsletter 46: 79-86.

Reddy BVS, Ramesh S and Rodomiro O (2010b) Genetic and cytoplasmicnuclear male sterility in sorghum. Plant Breeding Reviews 25: 139-172.

Ritter KB, David RJ, Scott CC, Ian DG, Emma SM and McIntyre CL (2008) Identification of QTL for sugar-related traits in a sweet $\mathrm{X}$ grain sorghum (Sorghum bicolor L. Moench) recombinant inbred population. Molecular Breeding 22: 367-384.

Ritter KB, McIntyre CL, Godwin TD, Jordan DR and Chapman SC (2007) An assessment of the genetic relationship between sweet and grain sorghums, within Sorghum bicolor ssp. Bicolor (L.) Moench, using AFLP markers. Euphytica 157: 161-176.

Shehzad T, Hisato O, Makoto K and Kazutoshi O (2009) Development of SSR-based sorghum (Sorghum bicolor (L.) Moench) diversity research set of germplasm and its evaluation by morphological traits. Genetic Resources and Crop Evolution 56: 809-827.

Shiringani AL, Matthias F and Wolfgang F (2010) Genetic mapping of QTLs for sugar-related traits in a RIL population of Sorghum bicolor L. Moench. Theoretical and Applied Genetics 121: 323-336.

Srinivas G, Satish K, Madhusudhana R, Reddy RN, Mohan SM and Seetharama N (2009) Identification of quantitative trait loci for agronomically important traits and their association with geneticmicrosatellite markers in sorghum. Theoretical and Applied Genetics 118: 1439-1454.

Stephens JC and Holland RF (1954) Cytoplasmic male-sterile for hybrid sorghum seed production. Agronomy Journal 46: 20-23.

Wang ML, Zhu C, Barkley NA, Chen Z, Erpelding JE, Murray SC, Tuinstra MR, Tesso T, Peterson GA and Yu J (2009) Genetic diversity and population structure analysis of accessions in the US historic sweet sorghum collection. Theoretical and Applied Genetics 120: 13-23.

Wen L, Tang HV, Chen W, Chang R, Pring DR, Klein PE, Childs KL and Klein RR (2002) Development and mapping of AFLP markers linked to the sorghum fertility restorer gene $r f 4$. Theoretical and Applied Genetics 104: 577-585.

Yu L and Cuizhen L (1998) Genetic contribution of Chinese landraces to the development of sorghum hybrids. Euphytica 102: 47-55.

Yun-long B, Yazaki S, Inoue M and Hong-wei C (2006) QTLs for sugar content of stalk in sweet sorghum (Sorghum bicolor L. Moench). Agricultural Sciences in China 5: 736-744.

Zhang G, Bharaj TS, Lu Y, Virmani SS and Huang N (1997) Mapping of the $R f-3$ nuclear fertility-restoring gene for WA cytoplasmic male sterility in rice using RAPD and RFLP markers. Theoretical and Applied Genetics 94: 27-33.

Zhou W, Kolb FL, Domier LL and Wang S (2005) SSR markers associated with fertility restoration genes against Triticum timopheevii cytoplasm in Triticum aestivum. Euphytica 141: 33-40. 